\title{
9 \\ Analýza české institucionální kultury. Proměny hranic mezi \\ soukromou a veřejnou sférou \\ v podmínkách každodennosti \\ a svátečnosti od poloviny 19. století do současnosti ${ }^{1}$
}

\author{
Analysis of Czech Institutional Culture. Transformation \\ of Boundaries between the Private and the Public Sphere \\ under Conditions of Everyday Life and Sacredness from \\ the Mid-19 $9^{\text {th }}$ Century to the Present
}

Karel B. Müller

\begin{abstract}
The aim of this article is to propose an interpretation and a critical assessment of institutional culture and its transformation in the Czech historical context. The framework of the analysis covers four succeeding nation-forming periods, from the mid-19th century up until the present day. It draws upon a sociological interpretation of the visual fact depicting a memorial of statehood, which was erected in 1919 in the village of Dolní Černošice. The analysis is further based on seven semistructured interviews with local councillors (from Černošice), on the quantitative questioner, and on participant observation. Silhouetted against the interpretation of the statehood memorial, the article attempts to answer questions regarding the main determinants of the transformation of institutional culture by drawing upon the dynamics of the relationships between the public and private spheres, their configurations and implications. The article contends that historically rooted asymmetries between the public and private spheres, which were embedded in the emancipation process of modern Czech society, have been greatly strengthened by the Communist period. In the post-communist period, institutional culture in the Czech Republic has been characterised by a high degree of institutional distrust and public stigmatisation of politics, as well as by a weakly developed virtue of (cognitive and political) opposition which is imbued with a discernible disrespect for discursive civic culture. A system of civic education is urgently needed if Czechs want to overcome the ominous deficits of their institutional culture.
\end{abstract}

KEY WORDS institutional culture, public sphere, (Czech) liberalism, post-communism, Czech Republic

Sociální studia / Social Studies 2/2017. S. 73-97. ISSN 1214-813X.

Studie vznikla v rámci projektu „Lokální politické elity jako klíčoví aktéři demokratizace“ podpořeném Grantovou agenturou České republiky (GAČR 14-12579S). 


\section{Úvod}

Cílem následující studie je interpretace a kritická reflexe institucionální kultury v českém kontextu, včetně porozumění dynamice jejích klíčových historických formativních konstelací a jejich implikací. Institucionální kulturou zde rozumím vztah občanské veřejnosti ke svým politickým demokratickým institucím. Brzy si budeme připomínat třicetileté výročí Sametové revoluce a ačkoli se Česko v jistém smyslu zařadilo mezi etablované demokracie Západu, máme k dispozici množství dokladů o tom, že kvalita demokratického vládnutí i kvalita občanské veřejnosti a její institucionální kultury se v Česku vyznačuje (jak oproti zemím severozápadu, tak ve srovnání s normativním pojetím liberální demokracie) významnými strukturními deficity (Frič 2008; Klíma 2015; Linek 2010; Lyons 2013; Müller 2016a; Müller 2018). Dnes již víme, že překonávání těchto deficitů nebude ani samovolné, ani jednoduché a že potrvá mnohem déle, než si mnozí na počátku devadesátých let mysleli. Předpověd’ Ralfa Dahrendorfa (1990) o potřebě třígenerační transformace „myslí i srdcí“ se dnes jeví jako předpověd' veskrze optimistická. Porozumění historickým formativním podmínkám, jejich kulturním závaznostem a determinismům představuje základní předpoklad překonávání těchto deficitů. Posilování liberální kultury předpokládá porozumění kontextu jejího historického formování, včetně omezujících a retardačních faktorů, které prosazování liberální kultury doprovázely.

\section{Metody}

Postup interpretace vychází vstříc požadavku metodologické triangulace. Využívá sociologickou metodu, která se zaměřuje na analýzu vizuálních faktů (Sztompka 2007). Jednotkou této analýzy je topografická situace vyobrazující veřejný prostor v pražské okrajové městské části (roku 2010), ve kterém je umístěn pomník připomínající vznik Československa v roce 1918. Tato topografická situace také vychází vstř́c diachronnímu rámování analýzy, které je ohraničeno polovinou 19. století na straně jedné a současností na straně druhé.

Primární data vztahující se k polistopadovému období byla nashromážděna také pomocí reprezentativního dotazníkového šetření, které proběhlo v listopadu 2014 v Černošicích, Semilech a Hrádku nad Nisou na celkovém vzorku 1100 obyvatel starších 18 let. Vzorek byl selektován na základě kvótního výběru dle věku a pohlaví. Šetření proběhlo formou 20minutového strukturovaného rozhovoru provedeného metodou CAPI a bylo realizováno ve spolupráci s agenturou IPSOS (Zpráva 2014). U všech třech měst byla předpokládána - na základě množství identifikovaných indikátorů - (na české poměry) nadprůměrná míra transparentnosti, otevřenosti i efektivity místní samosprávy (více viz Fleissner, Müller 2016; Müller 2016b; Müller 2018). Černošice, Semily i Hrádek nad Nisou jsme proto považovali za př́ípady dobrého vládnutí.

Kromě dotazníkového šetření bylo mezi červnem 2015 a květnem 2016 uskutečněno šest hloubkových polostrukturovaných rozhovorů s černošickými radními. Všichni vybraní účastníci rozhovorů byli považováni - na základě mnoha identifikovaných indikátorů - za nositele dobrého vládnutí, kteří ve svém městě prosazovali politické změny posilující transparentnost, otevřenost a efektivitu vládnutí (viz Müller 2018). Vybraní účastníci rozhovorů tedy vykazovali četné znaky liberálně-demokratických hodnotových orientací. 
Struktura dotazníku i polostrukturovaných rozhovorů vycházela z koncepce občanské veřejnosti a požadavku dobrého vládnutí (viz níže). Všechny rozhovory probíhaly v neformální a přátelské atmosfére, jejich délka se pohybovala v rozmezí jedné až půl druhé hodiny. Sada rozhovorů byla doplněna o jeden nestrukturovaný asi 20minutový rozhovor s majitelem statku, který přiléhá $\mathrm{k}$ interpretovanému vizuálnímu faktu (viz Seznam rozhovorů). Celkově jsme natočili přes 10 hodin zvukového záznamu.

Primární data byla získávána také metodou zúčastněného pozorování; mezi lety 2010 a 2017 byl autor stati zastupitelem města Černošice a v průběhu tohoto období si vedl výzkumný deník (Výzkumný 2017). ${ }^{2}$ Stejně jako struktura rozhovorů i dotazníku také perspektiva zúčastněného pozorování vycházela vstříc pojetí občanské veřejnosti, tj. především porozumění jednotlivým funkčním dimenzím a jejich vzájemným vztahům (viz níže). Stat' pochopitelně čerpá také z bohaté sekundární literatury, historických pramenů i ze šetření dalších výzkumných agentur.

\section{Teoretické zajištění interpretace - občanská veřejnost, svátečnost, identita}

Teoretické zajištění studie vychází z konceptuálního klastru „občanská veřejnost - identita - svátečnost". Nejrobustněji se studie opírá o koncepci diferenciace veřejné a soukromé sféry, které na Západě vedlo k formování liberální občanské veřejnosti (Habermas 2000). Doplňkově využivá také antropologický interpretativní př́stup k formování kolektivní identity (Shils 1975) a fenomenologické bipolární pojetí všedního a svátečního vnímání času (Taylor 1994).

\section{Občanská veřejnost}

Studie vychází z předpokladu, že dobré vládnutí se v demokracii nemůže rozvinout a udržet bez aktivní občanské veřejnosti, která se cítí za výkon svých institucí odpovědná. To zároveň předpokládá, že občanská veřejnost je schopna do těchto institucí investovat důvěru a že se s institucemi dokáže identifikovat. Občanská veřejnost jakožto podmínka dobrého vládnutí předpokládá jisté „procedurální“ srozumění a ctěni základních pravidel (institucí) občanského soužití, které teprve každému demokratickému vládnutí dodávají vitalitu a efektivitu.

Výzkum formování občanské veřejnosti a její konceptualizace se v západní sociální vědě odvíjejí od slavné Habermasovy práce z roku 1962 a pozdějších kritik, které vyvolala (Calhoun 1999). Hlavní význam občanské veřejnosti spočívá podle Habermase v tom, že umožňuje společnosti dospívat ke konstruování veřejného zájmu, a to v diskursu probíhajícím za hranicemi moci (který se však stal pro tuto moc normativní), tedy bez zprostředkování politickou sférou. Habermasovo pojetí občanské veřejnosti jakožto nově zrozeného způsobu utváření veřejného mínění i formování politické vůle klade klíčový důraz na roli kognitivních a racionalizačních diskursivních faktorů. Jak říká sám Habermas (2000: 156), občanská veřejnost dokázala „ve veřejné konkurenci soukromých argumentư“ konstruovat „konsensus o tom, co je v obecném

2 V Černošicích zajistili sběr rozhovorů kolegové $\mathrm{z}$ výzkumného týmu tak, aby byla garantována nezainteresovanost tazatele i dotazovaných. 
zájmu prakticky nutné“. Nezávislá občanská veřejnost je podle Habermase nutným předpokladem realizace principu suverenity lidu a hlavním zdrojem legitimity demokratických institucí. Zároveň je také zárukou rovného a otevřeného př́stupu občanů $\mathrm{k}$ diskusi o veřejných otázkách i přirozenou hradbou před nadměrnou expanzí politické moci a před jejím zneužíváním. Dominance kognitivně-diskursivních faktorů zajišstuje nejen férový a racionální průběh formování (a přezkoumávání) demokratických institucí a politické vưle, ale také možnost veřejného učení a kritického sebe/utváření společnosti samé. Užijeme-li sociologickou zkratku, veřejná sféra tak plní funkci divadla (Goffman 1956) i zrcadla (Luhmann 2006) zároveň, ve kterých se veřejnost předvádí i poznává způsobem, který vytváří př́ležitosti ke kritické reflexi a k učení se z vlastních omylů a nedostatků (Popper 1994).

Souhrnně řečeno, občanská veřejnost by měla ve vztahu k institucím plnit funkci legitimizační, participační, ochrannou, ale také funkci integrační, když konstruuje představu o sobě samé a o svém aktérství, včetně hranic své vlastní identity. Není pochyb o tom, že mezi těmito funkčními dimenzemi občanské veřejnosti existují četné reflexivní vztahy a resonance (Müller 2006). Tyto čtyři funkční dimenze a jejich vzájemné vztahy podmiňovaly strukturu získávání a vyhodnocování většiny našich primárních dat (tj. rozhovorů, dotazníku, zúčastněného pozorování).

\section{Kolektivní identita}

Předpokladem existence každé liberální společnosti je ovšem také požadavek, aby se občané cítili za stav volených institucí odpovědní a aby je takříkajíc prrijali za své. Legitimita politických institucí předpokládá i re/produkuje požadavek kolektivní identity. Legitimita a identita jsou spojeny pupeční šn̆ůrou, jež institucím zajišt'uje vitalitu a efektivitu. Jak ukazují mnozí sociální vědci (Hoover 1997; Morley 2000; Schmitt 2007), každý formativní proces kolektivní identity je nutně doprovázen konstruováním rozhraní mezi uvnitř a vně, mezi my a oni, mezi lidmi, kteř́ jsou zmocněni k politickému jednání v rámci svých institucí (demos), a těmi, kteří takové oprávnění nemají, a proto jsou vnímáni jako ne-známí, př́ípadně podezřelí, ba dokonce jako nebezpeční. Teorie kolektivní identity hovoří v této souvislosti o tzv. constitutive other/outside. Hranice produkují solidaritu k druhým lidem (uvnitř ohraničení) i loajalitu k politickým institucím, které veřejný život „uvnitř hranic“ organizují a chrání. Stejně tak mohou produkovat antagonismus vůči těm na druhé straně hranice.

Edward Shils (1975) rozlišil tři kódy (ideální typy) konstruování kolektivní identity, které se odlišují mírou prostupnosti či poréznosti ohraničení konstruované kolektivity. První kód prvobytnosti (primordial) se vyznačuje důrazem na neprostupnost hranice; tu mohou jedinci překonávat pouze narozením a smrtí. Dále rozlišuje kód posvátnosti (sacred), který umožňuje asimilaci, a kód občanskosti (civil), který vytváŕí nejpříhodnější podmínky pro občanskou integraci, jež trvá na loajalitě k pravidlům občanského soužití a k politickým institucím. Zatímco kód prvobytnosti dominantně resonoval v (rasových) koncepcích národa v průběhu 19. století, většina současných liberálních společností Západu v různé míre kombinuje kód posvátnosti a občanskosti a snaží se „citlivě vyvažovat dynamiku otevírání a opětovného uzavírání sociálně integrovaných životních světư“ (Habermas 2001: 81). 


\section{Svátečnost versus všednost}

S konstruováním kolektivní identity a historické paměti pak úzce souvisí vnímání času (Anderson 2003). Mnozí sociální badatelé pracují s bipolárním pojetím svátečního (sakrálního) a všedního (profánního) vnímání času (Petříček 1993; Taylor 1994). Svátečnost, která je jednou z trvalých souřadnic životního světa, představuje něco podstatnějšího než jen události profánního času, které jsou v jistém smyslu perspektivou svátečnosti teprve osmyslněny. Jak připomíná český filosof Miroslav Petrríček (1993), schopnost nahlížet svět z perspektivy svátečnosti i všednosti zároveň, a přesto reflektovat rozdílnost těchto dvou perspektiv, je v jistém smyslu předpokladem osmyslnění našeho životního světa.

$\mathrm{V}$ průběhu procesů modernizace došlo $\mathrm{k}$ radikální transformaci časo-prostorových vztahů a v souvislosti s procesy sekularizace a nástupem nacionalismu se posiluje význam „symbolických znaků“ (Giddens 1998), které jedince vyvazují z lokálních společenství a identitárně ho svazují s nově se formující národní společností. V souvislosti s růstem gramotnosti a posilováním role jazyka se prosazují nové formy de/konstrukce a re/konstrukce historické paměti. Objevují se nové artefakty posvátnosti, které re/konstruují hranice kolektivních identit, a procesy „ponárodňování“ jsou zároveň procesy „odnárodňování“ (srov. Urban 1995). Podobně jako náboženské rituály v tradičních či archaických společnostech staly se ve věku sekularizace a nacionalismu národní (či státní) pomníky a monumenty výrazem eschatologie moderního člověka. Stejnou funkci plní také pomníky uctívající hrdinné vzory nebo pomníky neznámým vojínům, jejichž anonymita pomáhá vyzdvihnout nadosobní a transcendentní povahu konstruovaného společenství.

Po základní interpretaci vazeb mezi občanskou veřejností, konstruováním kolektivní identity a vnímáním času, které v liberálních společnostech představují klíčový legitimizační nexus (dobrého) demokratického vládnutí, se přesuňme ke zdůvodnění diachronního rámování analyzovaného období a k představení interpretovaného vizuálního faktu.

\section{Představení vizuálního faktu a diachronní rámování interpretace ${ }^{3}$}

Interpretovaný vizuální fakt se nacházel na okraji Prahy v části Dolní Černošice, které jsou dnes součástí městské části Praha-Lipence a které byly do roku 1974 součástí obce Černošice. Místo jsem opakovaně míjel a zkoumal v jarních měsících roku 2010. Vizualizovanou situaci lze považovat za historickou a organicky vzniklou ,instalaci“ ve veřejném prostoru a za jedinečnou sondu do dějinného utváření politické a institucionální kultury a vzájemné dynamiky mezi státem a politickými institucemi na straně jedné a občanskou společností a kulturou (etnicitou) na straně druhé. Právě proměny vztahů mezi občanskou/etnickou společností a politickými institucemi (státem) jsou na vyobrazené situaci dobře symbolicky zachyceny. Tento topografický vizuální fakt reflektuje český historický kontext v časovém období zhruba od druhé poloviny 19. století až do současnosti. Konkrétní symbolické aspekty této topografické situace se $\mathrm{v}$ různé míre vztahují ke čtyřem specifickým státotvorným

Tato vizuální topografická situace byla poprvé a v hrubých rysech představena v popularizačním úvodu k monografii Češi, občanská společnost a evropské výzvy (Müller 2016a). 
i národotvorným obdobím moderních českých dějin - (schematicky řečeno) k habsburskému, prvorepublikovému, komunistickému a k polistopadovému období.

Topografie zde interpretovaného vizuálního faktu (Obrázky 1-4) tak vhodně odkazuje ke zvolenému diachronnímu rámování zkoumaného období. Pomník byl instalován v roce 1919 místními lidmi u př́ležitosti vzniku samostatného Československa (viz Obrázek 1). At’ už vznik Československa a jeho vztah $\mathrm{k}$ tradici české státnosti interpretujeme jakkoli, je neoddiskutovatelným faktem, že založení národního státu Čechů a Slováků bylo v době instalace pomníku vnímáno naprostou většinou etnických Čechů jako politické dovršení národně emancipačního úsilí, které vstoupilo do fáze masového politického hnutí v symbolickém roce 1848 . Konec první poloviny 19. století vskutku považuje naprostá většina českých historiografü za počátek politické emancipace české (národní) společnosti (Hroch 1999; Kořalka 1996; Urban 1978).

Obrázek 1: Pomník (s datací 1919) připomínající založení ČSR v roce 1918

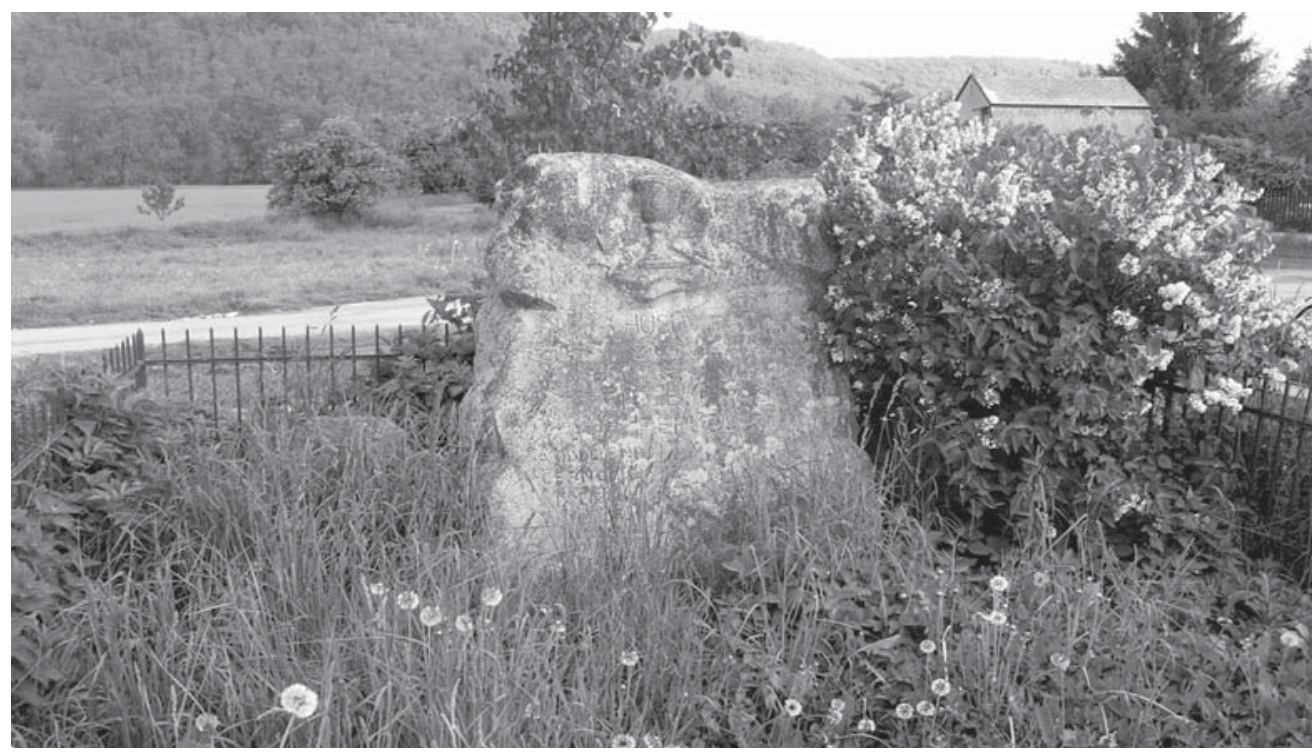

Zdroj: Archiv autora

Ačkoli pomník vznikl na počátku První republiky, vizualita celé situace více vypovídá o předchozím období a o obdobích následujících. Narativní architektura pomníku je výrazem hodnotových orientací jeho zakladatelů. Jak vyplývá z dolnočernošické kroniky (Pamětní 1919) a jak nám potvrdil také majitel usedlosti (rodák, dnes $\mathrm{v}$ důchodovém věku), před kterou se pomník nachází, zakladateli pomníku byli místní lidé, většinou sedláci (Rozhovor 7). Př́mo na pomníku je nápis „Tento Husův balvan zřízen přispěním všech občanů na pamět' zrrízení naší republiky a oddělení Černošic Dolních od Horních 1919“. Z nápisu samého je tedy zřejmé, že pomník byl instalován kolektivním jednáním všech občanů, dále i to, že akt rozdělení Černošic považovali místní lidé za pamětihodnou událost. Pomník tak připomíná dva zakladatelské akty a ve své dvojjedinosti symbolizuje étos separace; je to možné formulovat i tak, že pomník 
připomíná rok rozdělení habsburského státu a menším a níže posazeným nápisem (tedy méně kategoricky) také rok rozděleni Černošic. Jak se dozvídáme v dolnočernošické kronice (Pamětní 1919), ale např́klad také v práci Jiřího Boubína (2008), vztahy obyvatel Dolních a Horních Černošic byly vskutku zatíženy mnoha spory, které byly dány rozdílnou geomorfologií i sociální skladbou - kopcovité Horní Černošice s rostoucím vlivem pražské buržoazie na jedné straně řeky, na druhé straně řeky úrodně rovinaté a rolnické Dolní Černošice. Rozdílná sociální skladba je dodnes dobře patrná v charakteru sídelní struktury obou obcí.

V kronice Dolních Černošic se můžeme dočíst, že v létě 1929 byl Husův památník osazen „železným zábradlím“ a k pomníku přibyly dva postranní náhrobní kameny (Pamětní 1919). ${ }^{4}$ Zakladatelé pomníku se evidentně hlásili k Husovu evangelickému odkazu i k českému národnímu hnutí. Z kronikářských záznamů (Pamětní 1919) vyplývá, že občanskou veřejnost Dolních Černošic tvořili v době instalace pomníku především muži narození zhruba mezi lety 1860 až 1900, kteř́ dosáhli dospělosti v období habsburského státu, a jejich politická socializace byla tedy formována atmosférou posledních několika předválečných dekád. Architektonická narativita prvorepublikového pomníku je tak bytostně zakotvena, jak už bylo zmíněno, v mentalitě formující se české společnosti ve druhé polovině 19. století. Podoba přilehlého okolí je naopak dílem současníků, jejichž politická kultura byla formována kontextem komunistického a polistopadového období.

Symbolika topografické situace zřetelně odkazuje k rozhraní či střetávání soukromé a veřejné občanské sféry. Interpretovaná situace má povahu otevřeného prostoru, který představuje něco na pomezí křižovatky polních cest a venkovské návsi. Tento prostor zajištuje pohodlný a ze všech stran otevřený přístup $\mathrm{k}$ přilehlému soukromému statku, ke kterému je pomník orientován čelem. Veřejný pomník a soukromý statek tak ve své polaritě kompletují symbolický charakter vyobrazené situace (viz Obrázek 2). Formování veřejné sféry a občanské autonomie Habermas (2000) vskutku pojímá jako odvrácenou stranu nově zrozené lidské intimity a subjektivity, které se prosazují v rámci formující se soukromé sféry, jež je reprezentována měšt’anskou nukleární rodinou.

Pomník připomínající založení Československa v roce 1918 je nepochybným atributem veřejného. Pomník je symbolickým veřejným statkem, který je reprezentantem a připomínkou fundačního (zakladatelského) aktu, který novou (československou) občanskou veřejnou (a politickou) sféru vlastně teprve konstituuje. Instalace pomníku je projevem úcty k nově vzniklému státu a mechanismem nově konstruované (kolektivní) identity. Nejde však o ledajakou symboliku veřejného, nýbrž o symboliku nevšední, sváteční. Pomník je důkazem místního obecného přesvědčení o potřebě trvalé, výrazné a centrálně umístěné připomínce nezávislé státnosti jakožto uctívaného veřejného statku, kterým jeho zakladatelé zavazují sebe i své potomky odkazem k jednání předků. Pomník je jakousi „druhou mocninou“ veřejného statku, který kodifikuje transcendentní nárok kolektivní (národní) identity a který vznáší požadavek loajality ke státu i požadavek sounáležitosti a solidarity mezi zemřelými a ještě nenarozenými členy konstruovaného společenství (srov. Anderson 2003). Pomník

4 Jednalo se o památku na rolníka a starostu Dolních Černošic Ladislava Klána, který údajně zemřel roku 1916 v polní nemocnici na Sardinii, a o památku na pekařského pomocníka Josefa Jiskru, který padl při válečných operacích v bliže neupřesněném roce v Srbsku (Pamětní 1919). 
tedy reprezentuje historickou naraci a formu přisvojení kolektivní paměti, včetně nároků na atributy nově konstruovaného politického společenství (dému) v období těsně po rozpadu habsburského státu a v okamžiku vzniku Československa. Jeho smyslem je připomínat zakladatelský akt v exemplárním čase svátečnosti těm, kteří na ni ve všední den zapomínají. Jak k pojetí vztahu sakrálního a profánního argumentuje Charles Taylor (1994), zakladatelský čas nepatří do stejné kategorie jako současné jednání, jednoduše to není jen dř́ivější čin, nýbrž čin patř́íí $\mathrm{k}$ jiné časové rovině, $\mathrm{k}$ heroické době, kterou je třeba rituálně zpřítomňovat.

Obrázek 2: Veřejné versus soukromé: pomník české státnosti, opravená selská brána (datace 1810), v pozadí normalizační přístavba a před ní stojící míchačka s hromadou písku

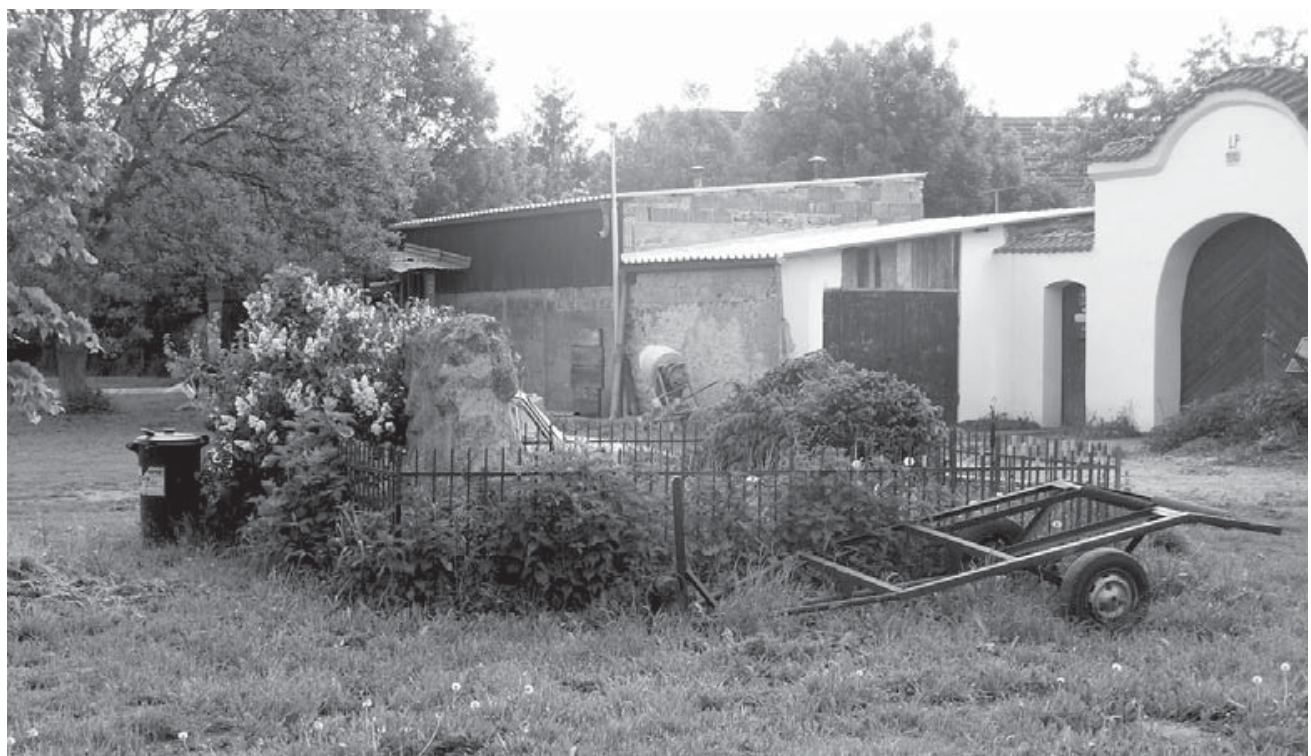

Zdroj: Archiv autora

V době výzkumu bylo okolí pomníku neúhledně posekáno, zřejmě aby byl zajištěn pohodlný př́istup k uskladněným věcem (a k popelnici). Posekaná tráva byla shrabána do rozvalené kompostující se kopičky, která je patrná u levého okraje Obrázku 2. Nápis na pomníku byl v době výzkumu značně omšelý a zpoza lina či přes vozík zcela nečitelný, takže mi nejdř́ve nebylo jasné, proč tam ten balvan vlastně je. Ostatně také majitel přilehlého statku, který si údajně jako malý kluk na Husově balvanu hrával, přiznal, že si vlastně není jist, co přsně je na pomníku napsáno (Rozhovor 7).

\section{Státoprávní proměny a jejich důsledky - habsburský a prvorepublikový kontext}

Jak bylo řečeno, pomník byl sice instalován na počátku První republiky, narativní architektura pomníku však vypovídá především o předchozím habsburském období. Podle Miroslava Hrocha (1999), který patř́i mezi nejvýznamnější západní historiky zabývající se 
nacionalismem, byly národotvorné procesy $\mathrm{v}$ českých zemích doprovázeny a formovány třemi klíčovými (a vzájemně provázanými) autostereotypy: pocitem ohrožení, důrazem na obranu a důrazem na jednotu. Také vizualizovaná topografická situace dokládá platnost Hrochovy interpretace, včetně dílčího porozumění sociální dynamice zmíněných autostereotypů $\mathrm{v}$ pozdějších obdobích. Tyto tři zmíněné stereotypy měly klíčový vliv na formování institucionální kultury v českých zemích ve druhé polovině 19. století a významně determinovaly její následný vývoj.

Prvním pozoruhodným rysem presentované vizualizace je skutečnost, že pomník připomíná skálu, tedy něco pevného, stabilního, neotřesitelného, ze země organicky povstávajícího. Narace pomníku tak jasně kodifikuje kolektivní identitu nově vzniklého státu na predpokladu primordiality či prvobytnosti, jež se vyznačuje neprostupným ohraničením konstruované kolektivity (Shils 1975). Primordiální pojetí kolektivní identity předpokládá narození jako jedinou možnou formu sociálního začlenění a stojí v pozadí všech rasových koncepcí národa. Symbolika „Husova balvanu“ tak jasně odkazuje k obrozenecké narativitě národního probouzení, jež dominovala mnohým národotvorným procesům ve střední Evropě a jež je konstruována na předpokladu primordiálního pojetí národa, který se jako monolit vynořuje $\mathrm{z}$ temnot dávnověku. $\mathrm{V}$ organické architektuře pomníku tak jasně rozpoznáváme Hrochem (1999) zmiňovaný důraz na jednotu, který byl posilován pocitem ohrožení (českého i německého etnika) a důrazem na obranu..$^{5}$

Český nacionalismus byl historicky ovlivněn a svázán s německým nacionalismem a s procesem budování jednotného německého státu, který započal v roce 1848 na ústavodárném shromáždění ve Frankfurtu a na který byli pozváni také zástupci českých zemí. Moderní česká veřejnost se utvářela ve vzdoru vůči veřejnosti německého jazyka, která byla v Čechách i na Moravě nepoměrně bohatší a dosti početná (v Čechách žilo přibližně $40 \%$, na Moravě zhruba 30 \% německojazyčných obyvatel). Český nacionalismus 19. století je svým pojetím reaktivní a ochranářský. ${ }^{6}$

Zřetelným symbolem obrany je dekorativní plůtek, kterým byl pomník státnosti v roce 1929 obehnán. ${ }^{7}$ Již zmiňované primordiální pojetí identity předpokládá konstitutivní význam neprostupného až odstrašujícího (tedy teritoriálního, z latiského terrere) ohraničení jako podmínku každé sociální organizace (Morley 2000). Etnické vymezování a (teritoriální

5 Svoji úlohu zde pochopitelně sehrávaly také tendence k odlišným formám identity (např. rakušanství, moravismus, bohemismus), které ovšem postupně slábly či zcela zanikly (Kořalka 1996). Jak poukazuje Otto Urban (1978), státoprávní úsilí české buržoazní politiky bylo ještě na počátku 70. let 19. století vedeno ve jménu ,politického národa“, kterým bylo chápáno jak české, tak německé etnikum v českých zemích. Nicméně tento přístup, jak dokládá opět Urban (1995), přestával hrát po nezdaru státoprávních snah v rámci tzv. fundamentálních článků v roce 1871 významnější roli (srov. také Malír 2014).

6 Tím však není řečeno, že zároveň nevychází také z osvíceneckých a liberálních impulsů, které staví do centra veřejného dění význam vědění a jazyka; ačkoli jak upozorňuje Urban (1995), česky psané osvícenství prakticky neexistovalo.

7 Možná, že plůtek měl také praktické zdůvodnění (ochrana před pasoucím se dobytkem), avšak zřetelná dekorativnost plůtku (včetně shora zašpičatěných výplní) jasně dokládá, že jeho tvůrci vkládali do ohraničení pomníku zřejmý symbolický obranný význam. 
i symbolické) ohraničování bylo (a ve střední Evropě zvláště) ústředním modernizačním mechanismem a kognitivním vzorcem, jehož vliv se posiloval také díky demokratizačním a liberalizačním změnám, které rozkládaly stavovskou hierarchii, de/rekonstruovaly kolektivní identity a zvýznamňovaly roli veřejného diskursu a jazyka.

Především z pohledu politické socializace představovala dominance primordiálního pojetí identity, jejímž konstitutivním znakem se stal právě jazyk, důležitou formativní sílu, která podlamovala hlubší zakořenění liberálních principů $\mathrm{v}$ institucionální a politické kultuře. Jazyk přestával být pouhým nástrojem dorozumění a stával se čímsi jako sakrální modlou (Rádl 1993; Kořalka 1996). Řečeno terminologií Anthonyho Giddense (1998), který mezi hlavní síly modernizace řadí tzv. vyvazující mechanismy, jazyk se stával symbolickým znakem, který jedince vyvazoval z tradičních uzavřených sociálních vazeb a opětovně ho (identitárně) zavazoval do symbolického rámce pomyslné národní společnosti (Anderson 2003).

Koneckonců u obou zemských jazykových skupin vyvolávaly jazykové konflikty výše zmíněné stereotypy (důraz na obranu a jednotu). Ačkoli německé etnikum bylo součástí a reprezentantem dominantního jazykového prostředí, podobnou kulturně-sociální dynamiku, která byla posilována českými jazykovými požadavky a postupnou demokratizací volebního práva, můžeme najít také mezi etnickými Němci v českých zemích (Hilf 1996; Malír 2014; Seibt 1996). To vedlo k tomu, že v sobě obě etnická společenství dlouho nenacházela dostatečné zdroje a prŕležitosti pro praktikování veřejné kritiky, natož politické opozice. Organické pojetí národa, pomocí něhož vysvětloval dynamiku etnického konfliktu ještě za První republiky také Emanuel Rádl (1993), výrazně podvazovalo svobodu slova a působení liberální ideologie, jejíž pronikání bylo eliminováno právě důrazem na esencializaci (českého) národního zájmu, jehož odvrácenou stranou byla obava z posilování pozice druhého zemského etnika.

Důraz na sociální jednotu znemožňoval širší rozvinutí smyslu pro názorový a zájmový pluralismus, který by umožnil zakořenění liberálního veřejného diskurzu a jeho institucí, včetně široce uznané (ale především praktikované) svobody slova. Diskursivní étos meziválečného Československa a jeho absenci smyslu pro názorový a zájmový pluralismus charakterizuje historička Eva Broklová (1992: 89) následovně: „Politické strany [...] měly spíš ráz strohých církví. [...] Diskuse mezi stranami nebyly věcí argumentů, nýbrž kaceřování. Člověk, který změnil členství v politické straně, neodešel, nýbrž zradil. Politické strany vykazovaly značnou dávku totalitního myšlení. Nebylo to přitom žádné novum. Už za Rakouska byly politické strany stranami maximálních programů, stranických dogmat a adventistické víry.“ Praktikování politické opozice lze přitom považovat za hlavní institucionální záruku svobody slova a veřejné kritiky. Habermas (2000) dokonce považuje uznání a instalování permanentní politické opozice za podmínku existence veřejné sféry jako takové.

Problém etnicko-jazykových skupin však nebylo možné řešit standardním principem parlamentarismu, tedy principem většiny. Většina, která byla vždy chápána etnicko-jazykově, zde nepředstavovala možný legitimizační nástroj řešení konfliktů. Etnická menšina se nikdy nemohla stát politickou většinou pomocí demokratických metod, aniž by nedošlo ke změně etnického ohraničení. Šlo o zablokovaný politický systém, který nenaplňoval zásadní podmínku rozvoje demokratické společnosti, sice otevřenost ve tvorbě většiny a možnou vzájemnou fluktuaci mezi většinou a menšinami (srov. Sartori 1993). Spolu s vyhrocováním 
etnického konfliktu se společnost $\mathrm{v}$ českých zemích postupně dostávala do situace, která neumožňovala řešení politických problémů dohodou a demokratickou cestou, nebot' obě její diferencující se etnika byla $\mathrm{v}$ různé míře stižena psychózou strachu z postavení menšiny, at' už demografické, hospodářské či politické, jež bránila nakloněnosti ke kompromisům. Jazykové skupiny se dostávaly do pozice programového antikompromisu, jenž byl podmíněný etnickým antipluralismem (Müller 2016a). ${ }^{8}$

Koneckonců také $\mathrm{v}$ narativitě zkoumaného pomníku jsou atributy nízké kapacity $\mathrm{k}$ dohodě a ke spolupráci jasně patrné. Rok poté, co se Češi rozešli s habsburskou monarchií, oslavují a do jednoho pomníku spolu s připomínkou založení československé státnosti dolnočernošičtí občané vyryli, že se rozcházejí s Horňáky, nebot', jak se dovídáme z dolnočernošické kroniky, jsou jejich zájmy zcela protichůdné a dohoda mezi nimi možná není (Pamětní 1919).

I když situace $\mathrm{v}$ meziválečném Československu nepochybně vedla $\mathrm{k}$ jisté liberalizaci poměrů, etnický konflikt nepolevoval. Obava z německé dominance byla transformována v obavu o stát (Broklová 1992). Nedocházelo zde k praktikování základního legitimizačního mechanismu, kterým je $\mathrm{v}$ demokracii střídání politických skupin u moci, tedy střídání vlády a opozice. Po celou dobu První republiky stála opozice (KSČ, Sudetoněmecká strana) na radikálně antisystémových pozicích, a hlavní politický proud tak byl donucen vládnout v duchu věhlasné teze „dohodli jsme se, že se dohodneme“, tedy způsobem předjednaných a veřejnosti nesrozumitelných zákulisních dohod mezi hlavními politickými stranami (Peroutka 1991).

Duch předjednaného kompromisu tím dosáhl svého maxima, čímž blokoval soutěživou, věcnou a argumentačně založenou politickou debatu, a tím i utváření argumentačně orientované občanské veřejnosti. Jak upozorňuje Raymond Aron (1993), úspěšné demokracie se musí naučit udržovat mezi duchem stranictví a duchem kompromisu rovnováhu, k čemuž slouží především argumentačně orientovaná veřejná sféra, ale také všeobecná úcta k formálním pravidlům a především $\mathrm{k}$ ústavě. $\mathrm{V}$ opačném případě se demokracie snadno zvrhávají nejdřive $\mathrm{v}$ chaotický anarchismus, poté v strnulý despotismus; obojí představuje málo efektivní a lidsky obtížně snesitelné formy vládnutí.

\section{Komunistický a postkomunistický kontext}

Nedostatečná identifikace $\mathrm{s}$ rakouským státem byla $\mathrm{v}$ komplikovaných prvorepublikových podmínkách vystř́íána kolonizací státu korporativním pluralismem (Heumos 1996), což se pak ukázalo jako dobrý předpoklad pro kolonizaci společnosti ze strany státu.

Zde je třeba zmínit, že na centrální úrovni došlo na Moravě v roce 1905 k progresivnímu kompromisu v podobě reformy volebního systému směrem k tzv. konsociační demokracii. Tato změna volebního systému vytváŕela prostor pro praktikování politické opozice uvnitř jednotlivých zemských etnik a byla výrazem inovativní institucionalizace jazykového konfliktu a př́slibem jeho produktivnějšího zvládání. Ačkoli se Moravským paktem inspirovaly další země i města habsburského státu, 1. světová válka z něj učinila slepou uličku dějin, nebot' poválečný vývoj nedokázal na tuto inovaci moderního konstitucionalismu, která se snažila smírit ideologie liberalismu a nacionalismu v jazykově heterogenním prostředí, navázat (Kelly 2003; Malír 2014). 
Z prvorepublikového „státu stran“ (Broklová 1992) se po únoru 1948 stává komunistická státostrana a „útěk od státu“ se postupně stával dominantním vzorcem institucionální kultury české „občanské“ veřejnosti (Holý 2001).

Pomník i dekorativní plůtek, které symbolizují úctu a potřebu obrany státnosti v kultuře jeho zakladatelů, kontrastuje s pozdější absencí systematické a trvalé péče o hodnotu státnosti (viz Obrázky 1-4). V době výzkumu byl plůtek prorezlý, na obou stranách pln vysokého pýru, kopřiv a pampelišek. Je všeobecně známo, že prvorepubliková státoprávní tradice byla komunistickou mocí tolerována, nikoli velebena. Ačkoli od roku 1989 je 28. říjen připomínán jako den vzniku samostatného československého státu a je státním svátkem, pomník neprošel rekonstrukcí a nebyl ani opečováván. Zanedbanost pomníku - po dvaceti letech liberální demokracie - symbolizuje trvanlivost „komunistického dědictví“‘.

Postkomunistická transformace byla významně ovlivněna zkušeností z období komunismu, kdy většina politických institucí postupně budovala svoji legitimitu na represivitě. Dominance (ačkoli nikoli nutně intenzita) této represivity se díky krizi legitimity komunistického režimu postupem času posilovala. Za normalizace oblíbené rčení „,kdo nekrade, okrádá rodinu“ dobře označuje legitimizační vakuum, do kterého se komunistický režim postupně propadal (Holý 2001; Mlčoch 2006; Možný 1999). Tato „morální maxima“ popisuje radikální kolizi principu legality a legitimity, kdy jednání, které bylo v souladu se zákonem (nekrást), bylo veřejností interpretováno jako morálně vadné (poškozující rodinu). V období normalizace dosahovala stigmatizace politické moci vrcholu a vymezování se vůči politice a politikům se stalo každodenním komunikačním rituálem (Holý 2001). Ten na straně jedné sloužil k posilování sociální soudržnosti mezi „obyčejnými lidmi“, na straně druhé byl výrazem opětovného „odstátnění“ české veřejnosti. Toto komunistické odstátnění bylo svojí dynamikou institucionální kultury v jistém smyslu analogické habsburskému období; politické instituce byly stále více vnímány jako něco cizího, vnuceného, ba nepřátelského.

Především posledních dvacet normalizačních let (1968-1989) silně posilovalo polarizační stereotyp „my“ versus „oni“, „obyčejní slušní lidé“ versus „,nomenklatura národních odpadlíkư “ podporovaná cizí sovětskou mašinérií (Holý 2001). V období normalizace postupně sílila role politické elity jako tzv. constitutive others, o jejichž nezastupitelném významu pro posilování sociální soudržnosti hovoří teorie kolektivní identity (Morley 2000; Shils 1975). Constitutive others sehrávají roli obětního beránka a jsou stereotypně označováni za příčinu selhávání a problémů většinové společnosti, čímž pomáhají posilovat sociální soudržnost většinové společnosti. V normalizačních podmínkách tak stigmatizace politiky a produkce symbolické polarity mezi údajně privilegovanými politiky a údajně obyčejnými občany paradoxně přispívala $\mathrm{k}$ částečnému tlumení sociálních konfliktů a ke stabilizaci sociálních poměrů. Tento polarizační stereotyp ,my versus oni“, který v průběhu komunistického období vedl k bezprecedentnímu oddělení soukromé a veřejné sféry (Holý 2001), vyvolával ve společnosti několik vzájemně provázaných efektů.

Za prvé vedl k potvrzování hodnoty soukromí (viz opravená selská brána na Obrázku 2). Jak argumentuje Piotr Sztompka (1998), v komunistických zemích střední a východní Evropy docházelo až k jakési adoraci soukromí. Většina lidí se obracela k rodině a soukromí jako sféře prožívání, ochrany a kultivace národních, náboženských či jiných symbolů a tradic. Realita přitom vyžadovala, aby většina obyvatel do veřejné sféry $z$ nejrůznějších důvodů 
vstupovala, at' už z profesních, odborných či kariérních důvodů. Ve své „veřejné“ roli byli tito lidé nuceni příležitostně hrát podle vnucených pravidel, jen aby mohli co nejdříve opět uniknout do své imaginární soukromé enklávy. Pestrý a materiálně zabezpečený soukromý život byl ze strany režimu také vehementně podporován (Vilímek 2010).

Druhým důsledkem, který bezprostředně souvisel s prvním, bylo znehodnocení veřejné sféry (viz zanedbaný pomník), a tedy politiky jako takové (Sztompka 1998). Komunistická strana opanovala veřejnou sféru - a nutno ř́ci, že s tichým „souhlasem“ velké části veřejnosti - souborem násilných a manipulativních metod. „Veřejnost" se pro komunistickou stranu stala pouhým nástrojem technologie moci. Především v období normalizace byla jakákoli hlubší spolupráce se státními institucemi, politiky či komunistickou stranou považována za nemorální, stigmatizující, za blízkou velezradě (Holý 2001). Proto ti, již se nehodlali smírit s vnitřní emigrací a chtěli se účastnit autentického politického života, si museli konstituovat svoji vlastní veřejnou sféru (paralelní polis) mimo oficiální struktury státu. ${ }^{9}$

Za třetí, jak argumentují ve vztahu ke komunistickým zemím střední Evropy již zmiňovaní Sztompka (1998) či Holý (2001), vedla tato situace k vytvoření pravidel dvojí morálky, morálky veřejné a morálky soukromé. Slušnost (civility) se stala soukromou ctností a přežívala na úrovni rodin, sousedství a přátel, ve „veřejné“ sfére se naopak šířilo barbarství (Holý 2001). S odvoláním na teorie modernizace a na nedávno zesnulého českého sociologa Iva Možného (1999), který označil komunistické období za jistou formu de-modernizace české společnosti, bychom mohli období normalizace charakterizovat také jako období de-institucionalizace politické sféry i občanské veřejnosti.

V každé demokracii představuje veřejná sféra hlavní prostředek řešení a institucionalizace sociálních konfliktů. Komunistická destrukce veřejné sféry (včetně znehodnocení jejich svátečních rituálů) neumožňovala svobodnou artikulaci a reprezentaci hodnot, zájmů a konfliktů, což vedlo, jak ukazuje Radim Marada (2003), k dalším dvěma negativním důsledkům. Na jedné straně docházelo ke skrytému narůstání sociálního napětí, na straně druhé občané nedokázali rozpoznávat svoji každodenní zkušenost jako politicky relevantní, a nemohli tudíž zaujímat relevantní politická stanoviska, orientace a o/pozice. Politické rozhodování mělo plně zákulisní charakter. Jak bylo již uvedeno, veřejná sféra se stala pouhou kulisou a prostředkem politické manipulace a dozoru ze strany KSČ. Veřejnost i její svátečnost byly privatizovány soukromými zájmy a politika pozbyla své hodnototvorné kapacity. Občané nemohli formovat specifické politické identity, tak jim nezbývalo než vůči politickému režimu zaujímat krajní postoje loajality či odmítání; v těchto souřadnicích občan utvářel obraz sebe samého jako politického aktéra (Marada 2003). Každodenní zkušenost občanů tak byla v jistém smyslu fenomenologicky de-politizována.

9 Na druhou stranu represivní povaha politické moci občanské protesty v jistém smyslu sama produkovala tím, že jakákoli svobodná aktivita se stávala politickým aktem se všemi jejími důsledky, což vedlo $\mathrm{k}$ politizaci celé řady primárně nepolitických aktivit. Tyto paralelní aktivity byly režimem důsledně potírány, což jim pak dodávalo punc a symboliku disentu. To platí nejen pro umělecký underground, ale do jisté míry i pro vlajkovou organizaci československého disentu Chartu 77 (Vilímek 2010). 
Obrázek 3: Uskladněné „na-paky“ v okolí pomníku

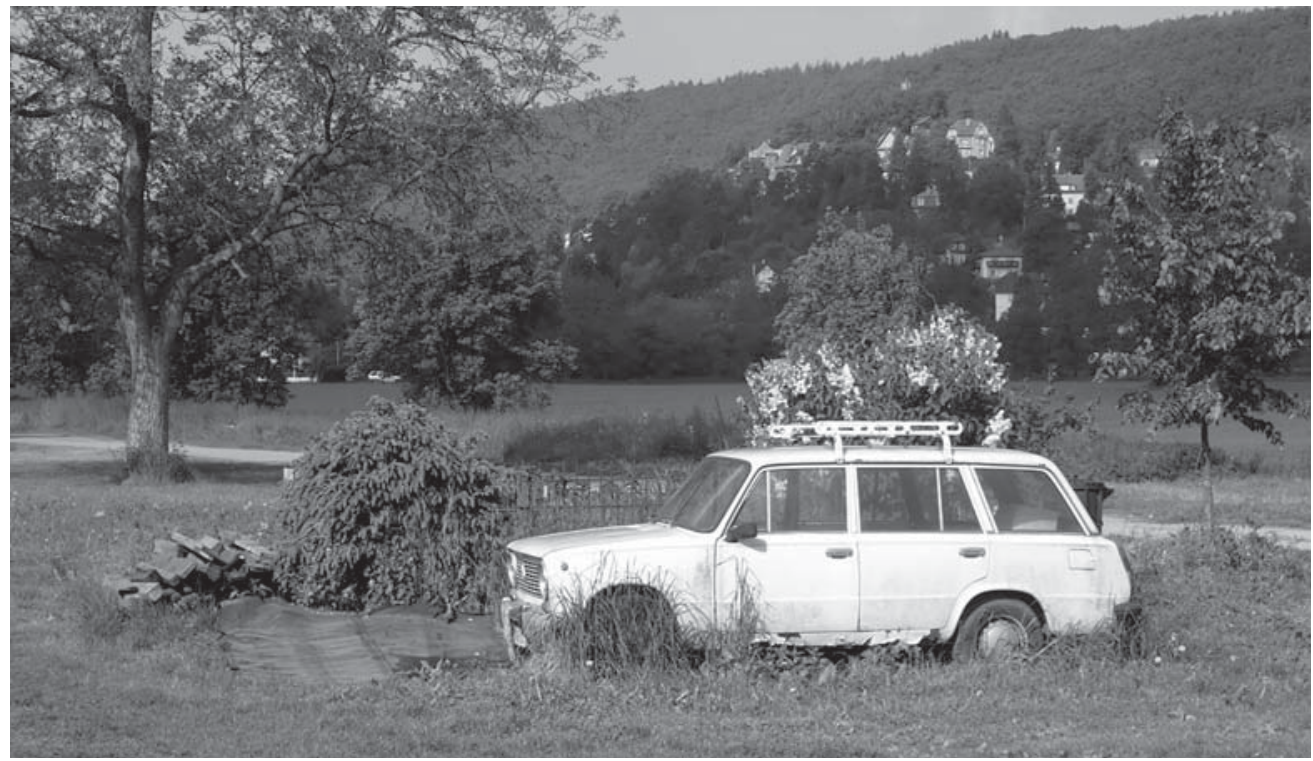

Zdroj: Archiv autora

Právě již zmiňované dramatické oddělení soukromé a veřejné sféry, ke kterému dochází v průběhu komunistického období, je v námi interpretované vizuální situaci dobře patrné. (Veřejná) sváteční připomínka státnosti je lemována uskladněnými (ale evidentně stále použitelnými) soukromými věcmi, které byly odloženy na místo, které je z hlediska všedního každodenního provozu dobře zřetelné a snadno př́stupné. Tyto na-paky (věci odložené na pak - vůz, lino, fošny a vozík) ohrazují připomínku státnosti do té míry, že komplikují přístup k pomníku samému. V místě nezorientovaný kolemjdoucí nemá šanci snadno identifikovat existenci pomníku, natož pak důvod jeho umístění (viz Obrázek 3). ${ }^{10}$

Pokud jde o význam na-paků, na první pohled to vypadá, jakoby pomník opravdu chránily, čímž na-paky odkazují ke zmiňovanému defenzivnímu auto-stereotypu české národní existence. Spíše však svojí partikulárností a všedností pomník zbavují původního významu a smyslu. Povaha na-paků odkazuje k normalizačním časům (fošny a linoleum) ochablé pracovní morálky, kdy se na pracovišti hodně kradlo (Možný 1999). Přisvojování si veřejných statků (vždyt' deklaratorně vše patřilo všem) mohlo mít ve veřejném povědomí i chvályhodné ideologické zdůvodnění, nebot' pomáhalo oslabovat centrálně ř́zenou ekonomiku a na ní založený a v době normalizace již naprostou většinou veřejnosti opovrhovaný komunistický režim (Holý 2001). Druhá polovina na-paků (vi̊z a vlečný vozík, viz Obrázek 4) pak odkazuje k normalizační „,chalupářské emigraci“ (Rupnik 2009), která představovala víkendovou enklávou úniku, svobody a důvěrnosti, jejíž pochopitelná adorace motivovala mnohé k jejímu zvelebování pomocí takto nelegálně (avšak

10 Za poskytnutí analyticky přesnějšího a empirickým výzkumem doloženého pojmu „na-paky“ děkuji jednomu $\mathrm{z}$ anonymních recenzentů textu. 
morálně) „redistribuovaných“ veřejných statků; vozík se zapřáhl za Ladu a vše (tedy v našem př́padě linoleum a fošny) se odvezlo na chalupu. Co se nevešlo na vozík, dalo se na zahrádku. ${ }^{11}$

Obrázek 4: Vozík, fošny, torzo živého plotu a neodborně zastřihávaný šeřík přiléhající k pomníku

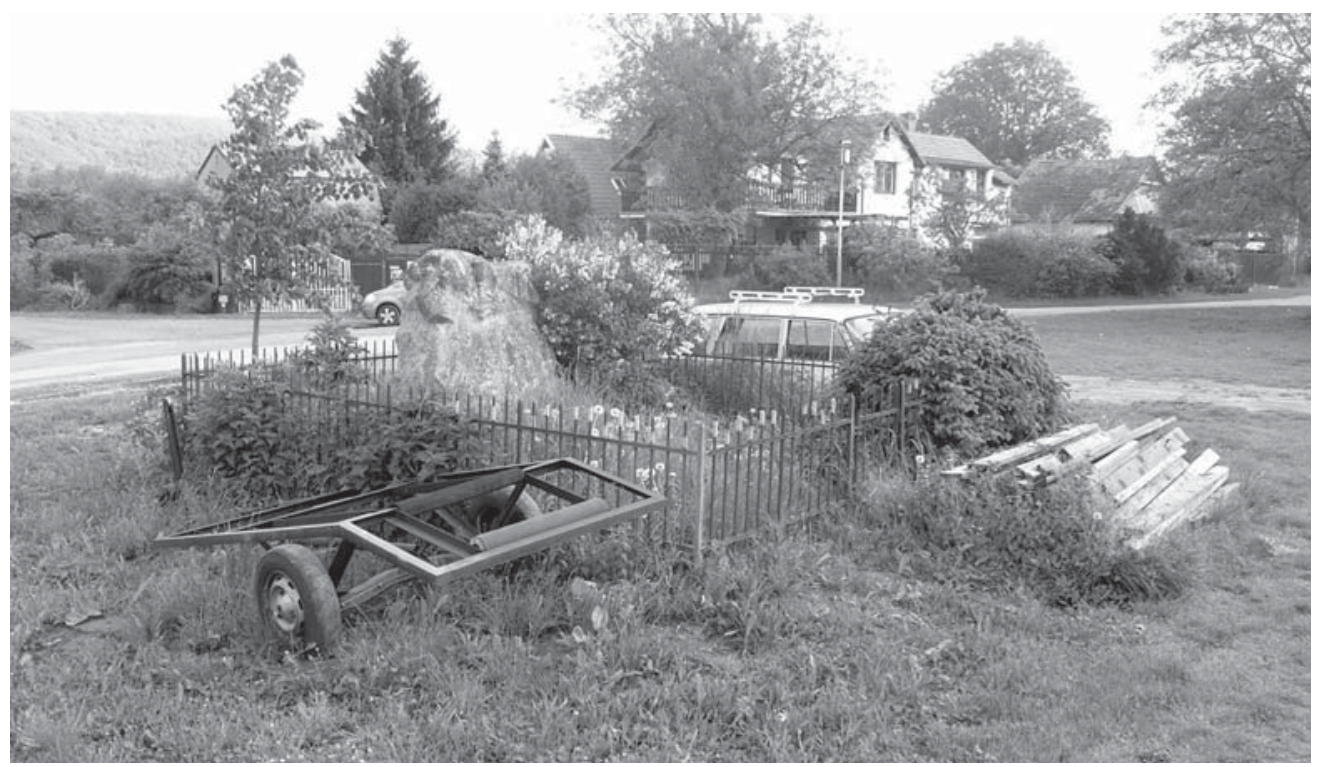

Zdroj: Archiv autora

Asymetrie vztahů soukromého i všedního na straně jedné a veřejného i svátečního na straně druhé je dále posílena kontrastem tohoto (soukromými na-paky obleženého, avšak přesto veřejného) pomníku s rekonstruovanou selskou bránou u přilehlého (soukromého) statku (viz Obrázek 2). Rekonstruovaná a pečlivě udržovaná pompézní brána statku (datace v průčelí vstupního portálu odkazuje k roku 1810) ostře kontrastuje s neomítnutou stěnou a sololitovou střešní krytinou normalizační přístavby, před kterou leží zbytková hromada písku s míchačkou, která je tak připravena ke každodennímu použití. Chatrná péče o veřejný pomník, jejíž př́iležitostnost i nesystémovost jsou ztělesněny v torzovitém (nicméně udržovaném) živém plotu v pravém předním rohu i v neodborně zastřihávaném šeříku, ${ }^{12}$ který přiléhá $\mathrm{k}$ pomníku z pravé strany, tak nachází svoji paralelu také $\mathrm{v}$ prrípadě přilehlého soukromého statku, jehož průčelí kombinuje jak různé architektonické styly, tak různé hospodářské (chtělo by se ř́ci „civilizačni“) př́stupy. Ve vyobrazené situaci tak nacházíme, co se péče o soukromý

11 O relativně vyšší míře sociální kontroly a mezilidské důvěry v dané lokalitě naopak svědčí skutečnost, že popelnice ani vozík nejsou k plůtku přivázány řetězem a místní se neobávají jejich odcizení. Za tento postřeh děkuji jednomu ze svých studentů, který pocházel z Libereckého kraje a který si údajně nedovedl představit, že by v místě jeho bydliště nedošlo bez dostatečného zabezpečení věcí k jejich brzkému odcizení (Výzkumný 2017).

12 Měl jsem možnost pomník zkoumat také za prítomnosti profesionální zahradníka (Výzkumný 2017). 
a veřejný zájem týká, zřejmou analogii. Rozhovor s majitelem protilehlého statku vskutku potvrdil, že jak „kolonizace“ pomníku prostřednictvím na-paků, tak péče o jeho okolí jsou společným dílem majitelů prrilehlých usedlostí (Rozhovor 7), kteří tak vkládají do utváření veřejného prostoru svoji soukromou estetiku.

Lze tedy shrnout, že pomník představoval centrum veřejné enklávy sloužící k hromadění soukromých věcí. Toto hromadění však nebylo hromaděním bez ladu a skladu, nýbrž mělo „smysl“" a jistou historickou „logiku“. Plastický pohled na tuto situaci symbolizuje polo/ moderní (Beck 2007) ráz české společnosti, ${ }^{13}$ která spontánně kombinuje upjatý tradicionalismus s neoliberální lhostejností (údajnou tolerancí) a která bezelstně připouští kolonizaci veřejné sféry soukromými (a ne vždy legitimními) zájmy. Ne-pořádek (absence řádu, anomie) „malého českého člověka“ je kompenzován - ve snaze nalézt funkční psycho-sociální ekvilibrium (Erikson 1974) - světoborectvím ,skvělého českého národa“ (Holý 2001). Tato znervózňující konstelace je vybalancovávána představou o vlastní nadřazenosti, která umožňuje snášet tuto iritující absenci řádu bez neuróz a patologických závislostí (srov. Giddens 1998). Nicméně Petrríčkův (1993) požadavek osmyslnění životního světa, který by měl vycházet ze schopnosti nahlížet svět (současně i odděleně zároveň) jak z perspektivy (veřejně-hodnotové) svátečnosti, tak z perspektivy (soukromě-každodenní) všednosti, ve vizualitě interpretované situaci evidentně nenacházíme.

\section{Institucionální kultura v současném Česku}

Institucionální kultura české veřejnosti je tedy dědictvím dlouhodobého historického formování a jedním z jejích konstitutivních a dlouhodobě působících faktorů je právě výrazná asymetrie mezi veřejným a soukromým, která podlamuje autoritu formálních pravidel, bez kterých se neobejde žádná liberální společnost (Alexander 2006). Tato asymetrie významně limituje kvalitu demokratického vládnutí i právního státu v současném Česku. Jak bylo již řečeno, žádná demokracie se neobejde bez aktivní občanské veřejnosti, která se cítí odpovědná za výkon svých institucí. Jak ukazují mnohé výzkumy (např. EES 2008; Frič 2008; Klíma 2015; Linek 2010; Lyons 2013; OECD 2016) včetně toho našeho (Müller 2016a, 2016b, 2018), institucionální kultura české veřejnosti se také v současnosti potýká (minimálně) se čtyřmi (vzájemně provázanými) deficity: (1) s vysokou mírou stigmatizace politické činnosti, která je prostoupena (2) nedostatkem smyslu pro zájmovou a názorovou pluralitu, jež vede k (3) podceňování významu veřejné diskuse při konstruování veřejného zájmu (a politické vůle). Slabě rozvinuté schopnosti i dovednosti ,dohadovat se“, stejně tak jako i dva předchozí zmíněné deficity, jsou reflexivně re/produkovanou součástí již zmiňovaného (4) podceňování významu formálních pravidel v každodenním (často konfliktním) občanském soužití. Součástí toho podceňování je také skutečnost, že formální pravidla jsou stále vnímána především jako prostředek represe, nikoli jako výraz a záruka občanské svobody a bezpečí.

Je třeba ještě jednou zopakovat, že ačkoli bezprostřední kořeny těchto deficitů nacházíme $\mathrm{v}$ komunistickém období a $\mathrm{v}$ polistopadové transformaci, jejich kořeny, jak bylo

13 Symbolem částečné modernizační vyspělosti české společnosti je osazení pomníku státnosti kontejnerem na svoz smíšeného odpadu v pravém zadním rohu (viz Obrázek 2). 
ukázáno výše, sahají mnohem hlouběji, sice až k samotným počátkům utváření moderní české společnosti ve druhé polovině 19. století. Česká společnost byla dominantně diskursivně formována na principu prvobytnosti a na autostereotypech ohrožení, obrany a jednoty (Hroch 1999; Malíř 2014; Kořalka 1996), které výrazně omezovaly prostor a př́ležitosti pro osvojování kultury veřejné kritiky a (názorové) opozice. Po roce 1989 se česká společnost učí budovat občanskou veřejnost (téměř) na zelené louce a nutno konstatovat, že historické dědictví se vykazuje nepř́ijemnou a překvapující rezistencí (path-dependency). Kvalita veřejného diskursu nepochybně podmiňuje také kvalitu politického soupeření a jak s poukazem na prvorepublikovou pětku, Národní frontu i polistopadovou „opoziční smlouvu“ argumentuje Rupnik (2009), také po roce 1989 si Češi obtížně osvojují uměni politické opozice. V Česku dominuje opozice vůči politice. ${ }^{14}$

Bylo by sice možné namítnout, že se jedná o „Zdravou“ nedůvěřivost vůči hegemonní politické moci a že jde vlastně o př́znivý liberální předsudek (srov. Pithart 2014). Ukazuje se však, že zmiňované deficity institucionální kultury nejsou „výsadou“ vysoké politiky. Průzkum provedený v Černošicích, Semilech a Hrádku nad Nisou, které lze v českých poměrech považovat za prípady obcí s vysokou mírou efektivity a transparentnosti vládnutí a které představují otevřenou politickou strukturu s množstvím participačních příležitostí (Müller 2018), přinesl zřetelné projevy všech čtyř zmíněných deficitních znaků: tedy jak vysoké stigmatizace politické činnosti a podceňování významu diskuse i formálních pravidel, tak slabého smyslu pro zájmovou (a názorovou) pluralitu. ${ }^{15}$

Bylo pro nás překvapivé, že jsme právě v Černošicích, kde žije $30 \%$ vysokoškolsky vzdělaných občanů, kteří spolu se středoškoláky (s maturitou) tvoří přes $60 \%$ obyvatel města, naměřili (v roce 2014) vysokou míru stigmatizace politiky a distance vůči politické činnosti. Vysokých 44 \% černošických dotázaných uvedlo, že „od politiky je dobré dát ruce pryč“, nebot', ,jde o špinavou záležitost“". V Semilech to by ještě nepatrně vyšší procento dotázaných (47 \%) a v Hrádku nad Nisou dokonce většina (51 \%) dotázaných (Zpráva 2014). Je v jistém smyslu paradoxní, že místní politici - jak vyplývá ze všech provedených rozhovorů s černošickými radními - jsou téměř vždy sami nevědomky nositeli stigmatizace politické činnosti tím, že se od toho „být politikem“ raději více, či méně veřejně distancují (Rozhovory 1-6). Tento postoj je však v jistém smyslu pochopitelný, nebot' jak dokládají výzkumy Pavola Friče, na začátku nového tisíciletí vnímala většina občanů politické elity jako sebestředné, nekompetentní a všeobecně podezřelé, které - na rozdíl od jiných sociálních elit - společnosti údajně nic nepřinášejí. Většina veřejnosti měla dokonce za to, že mnozí př́islušníci politické

14 Koneckonců po volbách v roce 2013 úspěšně provozoval politický marketing apolitičnosti ministr financí a majitel Agrofertu Andrej Babiš. V roce 2017 dokonce hnutí ANO suverénně vyhrálo s protestním apelem anti-politiky sněmovní volby. Těžko bychom hledali reprezentativnější průzkum institucionální kultury. V době revidování tohoto textu sestavoval premiér Andrej Babiš vládu s programovým prohlášením, které slibovalo všeobecně (tedy jednoznačnou a bez-konfliktně) prospěšnou vládu odborníků.

15 V Semilech a Hrádku nad Nisou byly zmíněné deficity institucionální kultury většinou ještě výraznější než v Černošicích, což bylo možné - vzhledem k nižšímu vzdělanostnímu i socioekonomickému statusu semilské i hrádecké veřejnosti - předpokládat. Spíše nás překvapilo, že rozdíl oproti Černošicím byl v mnoha ohledech velmi malý, ba zanedbatelný. 
elity by nebyli schopni se mezi společenskou elitu - jinak než pomocí politické kariéry vůbec povznést. Frič dochází k jednoznačnému závěru, že Česko bylo doposud zemí se silně negativním vůdcovským klimatem, kdy mezi veřejností a politickými elitami převládá pocit vzájemného despektu (Frič 2008). ${ }^{16}$

Také pokud jde o podceňování veřejné kritiky a významu diskuse, ukázaly Černošice překvapivě vysokou poptávku po autoritativnějším stylu politiky. Vysokých 38 \% dotázaných nepovažovalo veřejnou diskusi za dobrou cestu k řešení obecních problémů, a dokonce ještě vyšších 65 \% dotázaných považovalo konfliktni diskusi za prekážku při řešení obecních problémů. Převažující většina (62 \%) dotázaných se pak domnívala, že pokud má člověk dobrý záměr, je dobré ho prosadit bez dlouhého schůzování a $41 \%$ občanů měla za to, že jsou-li lidé slušní a rozumní, dojdou vždy k jednomyslnému stanovisku (v Semilech tento názor zastávalo celých $54 \%$ dotázaných a v Hrádku nad Nisou dokonce $58 \%$ dotázaných). Tyto údaje signalizují slabě rozvinutý smysl pro zájmovou a názorovou pluralitu, což je po pětadvaceti letech svobodných poměrů v obci, kde žije 30 \% vysokoškoláků a kde 95 \% dotázaných deklaruje spokojenost se životem, nemilým překvapením (Zpráva 2014).

Také poznatky z rozhovorů s černošickými radními poukazují na nízkou úroveň diskursivní kultury. Své rozčarování nad kvalitou veřejné komunikace shrnul černošický radní Tomáš Hlaváček následovně:

Vadí mi bez ohledu na obsah ty tóny komunikace, která je a priori postavená... všechno je špatně a [občané] neříkají, jak by to mělo být jinak. Tak to je to, co mě nejvíce unavuje, bez ohledu na obsah. A naopak jakoby, at' už ten obsah je jakýkoli, tak když to člověk řekne tak nějak normálním tónem. Stalo se tohle, ale navrhoval bych tohle, tady jsou důvody, proč by to tak šlo, tak to je fér... ale takových je minimum. [...] Většinou když už se někdo ozve, je to neuvěřitelně urputné... je z toho cítit, jak má dvojnásobně zvýšenou tepovou frekvenci a jenom jakoby ten vztek $\mathrm{z}$ toho čiší. Ale nedá se s tím nic moc dělat. (Rozhovor 4)

Velmi podobně vylíčil své vnímání veřejné komunikace také starosta Černošic:

Myslím si, že toho negativismu je tolik, že pokud se mu nebudeme aktivně bránit, tak ta společnost na tom není dobře. Pořád tam vidím velký rozdíl oproti [Západu], v tomhle vidím velký deficit český společnosti. Neumíme se ani vyjadřovat, neumíme komunikovat... (Rozhovor 2)

Efekty stigmatizace politiky a despektu k diskusi, které nacházíme také na mikroúrovni, jsou doprovázeny (a posilovány) vysokou mírou odtažitosti české veřejnosti od politiky vůbec. Podle průzkumu European Social Survey z roku 2008, který proběhl také v Česku, pouhých 4,7 \% respondenti̊ uvedlo, že politika pro ně představuje ,velmi důležitou“ věc

16 Začarovaný kruh apriorní nedůvěry vůči politickým institucím a jejich představitelům (držitelům) má mnoho negativních a vzájemně provázaných dopadů na politickou kulturu: mezi ty nejvážnější lze zařadit (1) občanskou demobilizaci, (2) negativní selekci politických elit a (3) rychlý efekt vyhoření na straně politických elit, jež může vést (4) jak k uzavírání se, tak ke zcyničtění, případně k obojímu. Lze dokonce konstatovat, že politická činnost (podobně jako v období komunismu) stále představuje formu sociální exkluze. 
(ESS 2008). ${ }^{17}$ Také výzkum OECD publikovaný v roce 2016 ukázal, že v Česku se z věkové skupiny 15 až 29 let o politiku vůbec nezajímalo 57 \% dotázaných, což představovalo druhý nejhorší výsledek ze všech zkoumaných zemí (OECD 2016). Velmi podobná zjištění přinesl i náš vlastní výzkum př́ípadů dobrého vládnutí. Intenzivní zájem o politické dění deklarovala pouhá $4 \%$ černošických občanů - a shodně pouhé $1 \%$ semilských i hrádeckých občanů zatímco $63 \%$ černošických deklarovalo nezájem a v Semilech a Hrádku nad Nisou opět shodně vysokých $67 \%$ občanů (Zpráva 2014).

Také pokud jde o deficit důvěry ve formální pravidla, přinesl náš výzkum mnohé důkazy o tom, že nedoceňování významu formálních pravidel (a diskuse) představuje výrazný (možná dominantní) rys institucionální a politické kultury v Česku. Dokládají to desítky situací zaznamenaných v rámci sedmiletého zúčastněného pozorování (Výzkumný 2017). Uvedu zde dvě z nich.

Když v roce 2014 v Černošicích městská rada organizovala konkurs na výběr ředitele základní školy, kladla důraz na transparentnost a férový průběh konkursu tak, aby byl vybrán nejkvalitnější kandidát. Naprostá většina pedagogického sboru si však prála výběr interního kandidáta a zasahování zřizovatele (tedy města), který je povinen zorganizovat transparentní a otevřený konkurs, vnímala jako neoprávněné. Bylo pro mne překvapením, když jedna učitelka interpretovala kroky zřizovatele, které jsou ze zákona povinné (a které osobně považuji za rozumné), jako formu politické a nemorální šikany s tím, že situace ve škole je přece v naprostém pořádku, nebot' v ní pracují „samí slušni lidé, kteří si nezaslouží, aby o jejich novém vedení rozhodoval někdo zvenčí, někdo jiný než oni sami, a už vůbec ne nějaké formální procedury (Výzkumný 2017; Müller 2016b). Jak se později ukázalo, tento názor zastávala naprostá většina zhruba padesátičlenného pedagogického sboru, který nedokázal zabránit (nýbrž pasivně přihližel či aktivně podporoval) rozvratnému konfliktu mezi některými učiteli a novým vedením školy. Rok trvající mobbing skupiny učitelů nakonec vedl k dobrovolné resignaci ředitelky, která $\mathrm{v}$ konkursu vyhrála. Konflikt, jehož průběh byl rozhodně ne-občanský (uncivil), nebot' na straně některých učitelů došlo k jednání, které bylo za hranou jak profesní etiky, tak prosté lidské slušnosti, vedl k destabilizaci celé instituce. Tento př́pad nejenže svědčí o přetrvávajícím výše zmiňovaném represivním vnímání politických institucí, ale poukazuje také na zajímavou formu klientelistické institucionální imploze. Reprezentanti institucí jsou důležitější než instituce samé, proto se stávají jejich držiteli. Tato zkušenost vysvětluje mnohé problémy s rozvinutím organizační kultury, která by v liberální demokracii měla být založena na reflexivitě institucí a která by měla zajišt’ovat jejich utváření směrem k vyšší efektivitě, otevřenosti a inovativnosti.

Druhý př́ípad - na jaře 2014 jsem se účastnil interní „politické“ diskuse o tom, jak posílit prestiž a efektivitu naší městské policie. Zaujal mne vyhraněný a důrazný názor jednoho z př́tomných policistů (šlo o policistu ve vedoucí pozici s dlouholetou praxí u pořádkových složek), že „vynucování pořádku nebude nikdy oblíbené“ (Výzkumný 2017). Kladu si od té doby otázku, čím to je, že Češi nemají rádi vynucování pořádku. Nemají snad Češi rádi pořádek? To si rozhodně nemyslím. Spíše se kloním k názoru, že nemají rádi vynucování. Také tento postoj vyplývá z přetrvávajícího represivního a nedůvěřivého vnímání pravidel a institucí

17 Bylo to ještě o něco méně než v případě náboženství, které za ,velmi důležité“ považovalo $6,3 \%$ dotázaných (ESS 2008). 
a z nedostatku úcty $\mathrm{k}$ formálním pravidlům jakožto záruky bezpečí, sociálního řádu i občanské svobody.

Připomínám, že v Černošicích jsme předpokládali nadprůměrnou vyspělost občanské veřejnosti. Náš výzkum ukazuje, že pokud občané komunikují s veřejnými představiteli o svých zájmech a požadavcích, často vyžadují neformálnost a zvláštní ohledy (třeba s poukazem na to, že jsou přece „slušní“ lidé); pokud však komunikují o zájmech a požadavcích svých spoluobčanů, které jsou s jejich zájmy v rozporu, vyžadují dodržování formálního postupu (Rozhovory 1, 3; Výzkumný 2017). Jinými slovy to vypadá, že mnozí občané prosazují kulturu formálních pravidel pouze tehdy, je-li to pro ně výhodné, což je př́stup, který je z logiky věci v rozporu se samotným principem formálních pravidel (Müller 2016b). Jako kdyby se občané podřizovali pravidlům pouze $\mathrm{v}$ konfrontaci s represivní povahou politické moci, nikoli z důvodu vlastní důvěry ve formální pravidla jakožto záruky předvídatelnosti, bezpečí a svobody.

\section{Co dělat?}

Položme si na závěr obecnou otázku, jak lze institucionální kulturu formovat. Jak posilovat autoritu formálních pravidel i občanských kompetencí? Vztah občanské veřejnosti k demokratickým institucím (a ke státu) je součástí institucionální a politické kultury a jejích kognitivních, symbolických i normativních faktorů (Delanty 2011), jejichž utváření je ovlivňováno mnoha vnějšími i vnitřními faktory (Rose, Mishler 2010). Mezi hlavní vnitřní faktory řadíme na jedné straně výkonnost těchto institucí. Mezi klíčové vnější faktory na straně druhé řadíme právě sdílenou zkušenost a historické tradice, které slouží ke konstruování a institucionalizaci kolektivní paměti a identity. Již celá desetiletí probíhají mezi sociálními vědci diskuse o tom, které z faktorů hrají při formování vztahů mezi občanskou veřejností a jejími institucemi nejvýznamnější roli. Záleží především na závaznosti historických tradic (path-dependency), jak se např́iklad domnívá (a na příkladu Itálie přesvědčivě dokládá) Robert Putnam (1993), nebo spíše na výkonnosti institucí samých, jak se například domnívá (a na př́kladu Švédska přesvědčivě dokládá) Bo Rothstein (2004)? Tento spor zřejmě zůstane nerozhodnut s tím, že dominance těch či oněch faktorů je vždy dána konkrétním historickým kontextem a specifikami socioekonomických, politických a kulturních konstelací.

Rozhodně však mezi badateli panuje shoda v tom, že mezi výkonností institucí a sdílenou historickou zkušeností existují reflexivní vztahy a resonance, tedy že institucionální tradice a sociokulturní kontext podmiňují výkonnost institucí na straně jedné a že výkonnost institucí může ovlivňovat sociokulturní kontext i institucionální tradice na straně druhé. Jak dokládá případ Česka i některých dalších postkomunistických zemí, vztah důvěry a institucí se vyznačuje začarovaným kruhem sebe/naplňujícího proroctví. Despekt k demokratickým institucím odrazuje od politického angažmá, demobilizuje veřejnost a podlamuje občanské kompetence, čímž eroduje klíčové předpoklady nutné k posilování výkonnosti demokratických institucí. Skutečnost, že demokratické instituce fungují zle, zpětně vede k znevažování těchto institucí. Na druhou stranu při pohledu na jiné země (už zmiňované Švédsko či válkou zdevastované Německo) vidíme příklady kulturně adaptačních změn vedoucích k posilování institucionální důvěry a veřejné odpovědnosti za demokratické instituce. Vztah odpovědnosti a důvěry k demokratickým institucím 
naopak občanské kompetence posiluje (a částečně předpokládá) a pracuje ve prospěch institucí, které jsou výkonné, otevřené a odpovědné zájmům svých občanů.

Zdá se, že apriorní veřejná nedůvěra vůči demokratickým institucím za určitých podmínek podlamuje efektivitu a reflexivitu institucí, veřejná důvěra naopak posiluje u institucí jejich servisní funkci i jejich efektivitu. Předem není nikdy jisté, jakým směrem se bude dynamika vztahu výkonnosti demokratických institucí a kulturních předpokladů ubírat. Je však jisté, že demokratické instituce mohou důvěru, jež je zdrojem identifikace s těmito institucemi, jak vytvářet, tak destruovat. Snaha o posílení důvěryhodnosti institucí pomocí tlaku na jejich efektivitu, otevřenost a transparentnost má nepochybně smysl. Je to však v jistém smyslu podmínka nutná, nikoli dostačující. Pokud chceme zajistit udržitelnost dobrého vládnutí a institucionální efektivitu, neobejdeme se bez tlaku „zdola“, který může zajistit jedině systematický a dlouhodobý program politické socializace ve prospěch liberálně demokratických hodnotových orientací. Je trestuhodné, že česká občanská veřejnost ani její politická reprezentace prozatím nebyly schopny se na potřebnosti zavedení takového programu, natož na jeho vytvoření, dohodnout.

Nejen systém občanského a politického vzdělávání, ale nepochybně také rodina hraje v procesu politické socializace klíčovou roli. Můžeme předpokládat, že demokratické instituce mohou vytvářet důvěru jednak prrímo prostřednictvím své výkonnosti, ale také nepřímo prostřednictvím ovlivňování sociálního klimatu, který formuje obsah i formy komunikace uvnitř i na pomezí nukleární rodiny a významně ovlivňuje procesy primární i sekundární socializace (Uslaner 2002; Giddens 1998).

\section{Shrnutí}

Cílem stati byla interpretace a kritická reflexe institucionální kultury v českém prostředí, včetně interpretace a porozumění hlavním historickým státotvorným/národotvorným faktorům a konstelacím. Diachronní analýza byla rámována polovinou 19. století na straně jedné a současností na straně druhé. Interpretace se opírala o využití sociologické vizuálně interpretační metody, která analyzovala vyobrazenou topografickou situaci a její kulturně-institucionální charakteristiky, vycházela také z polostrukturovaných rozhovorů, dotazníkového šetření, zúčastněného pozorování i sekundární literatury a pramenů. Teoretické zajištění studie vycházelo z pojmového klastru „občanská veřejnost - svátečnost - identita“, který využívá koncepci diferenciace veřejné a soukromé sféry (Habermas 2000), fenomenologickou typologii všedního a svátečního pojetí času (Taylor 1994) a antropologickou typologii kolektivní identity (Shils 1975).

Interpretovaná vizuální situace vypovídá o (pravděpodobně největší) slabině české institucionální kultury, sice o přetrvávající výrazné asymetrii mezi veřejným a soukromým. Tato asymetrie je dědictvím dlouhodobého historického vývoje. Její kořeny sahají minimálně ke zkušenostem mnohageneračního etnického napětí a národnostních konfliktů v českých zemích ve druhé polovině 19 . století. Tyto konflikty vyvazovaly jedince z usazených tradičních sociálních vazeb, aby je identitárně znovu zavazovaly do pomyslných rámců národních společností, které byly kodifikovány na předpokladu prvobytnosti a jazykově pojímané etnicity. Etnické identity občanů českého a německého jazyka byly postupně konstruovány na principu výlučnosti. Obava z dominance či asimilace neumožňovala rozvoj názorové 
a zájmové plurality a pěstování kultury veřejné kritiky a opozice. Tento fakt významně omezoval působení liberálních principů a požadavků a podlamoval rozvoj veřejné sféry a diskursivně-kulturních podmínek, které umožňují zakořenění liberálně-demokratického vládnutí a které posilují jeho odolnost. Asymetrie vztahů mezi veřejnou a soukromou sférou byla výrazně posílena komunistickým obdobím, především normalizačním znehodnocením veřejné sféry a politiky. V nových konfiguracích se tato asymetrie opět projevila po roce 1989.

Podobně jako mnozí sociální vědci (Frič 2008; Mlčoch 2006; Možný 1999; Sedláčková 2012) také tato studie argumentuje ve prospěch tvrzení, že hlavní problém rozvoje demokracie $\mathrm{v}$ Česku spočívá $\mathrm{v}$ nedostatečném vztahu $\mathrm{k}$ demokratickým institucím. Náš vlastní výzkum posiluje hypotézu, že jde o strukturní deficit, který vychází z hluboce zakořeněných kognitivních vzorců i vzorců politického chování, a že prostupuje všechny úrovně vládnutí, a že tedy nejde o specifikum „vysoké“ politiky. Slabost politických institucí (a formálních pravidel) znesnadňuje zabezpečení veřejných institucí před kolonizací soukromými zájmy. Součástí nízké institucionální důvěry je vysoká míra stigmatizace politické činnosti, slabě vyvinuté umění (politické) opozice i ostatních diskursivních kompetencí, podceňování významu diskuse při konstruování veřejného zájmu i slabě rozvinutý smysl pro zájmový a názorový pluralismus. Tyto deficity ve svém součtu představují vstupenku pro politický populismus, který je živen jednoduchou a nebezpečnou představou o tom, že společnost se dělí na zkorumpovanou a sebestřednou politickou elitu na straně jedné a na „obyčejné lidi“, kteří jsou nositeli jednotné a ne-konfliktní politické vůle na straně druhé.

Tabulka 1: Seznam účastníků rozhovorů

\begin{tabular}{|c|c|c|c|c|c|c|c|}
\hline Rozh. & Funkce & Obec & $\begin{array}{l}\text { Politická } \\
\text { př́slušnost }\end{array}$ & $\begin{array}{l}\text { Naroz., } \\
\text { vzdělání }\end{array}$ & Zaměstnání & $\begin{array}{l}\text { Datum } \\
\text { rozhov. }\end{array}$ & Jméno \\
\hline 1 & $\begin{array}{l}\text { zastupitelka } \\
\text { od } 2006 \text {; radní } \\
\text { od } 2010\end{array}$ & Černošice & $\begin{array}{l}\text { Věci } \\
\text { černošické }\end{array}$ & $\begin{array}{l}1973 \\
V \check{S}\end{array}$ & $\begin{array}{l}\text { vysokoškolská } \\
\text { pedagožka }\end{array}$ & 10. 6.2015 & $\begin{array}{l}\text { Lenka } \\
\text { Kalousková }\end{array}$ \\
\hline 2 & $\begin{array}{l}\text { zastupitel od } 2006 \text {; } \\
\text { starosta od } 2010\end{array}$ & Černošice & $\begin{array}{l}\text { Věci } \\
\text { černošické }\end{array}$ & $\begin{array}{l}1973 \\
V \check{S}\end{array}$ & $\begin{array}{l}\text { starosta, ředitel } \\
\text { konzultační } \\
\text { společnosti }\end{array}$ & 2. 7. 2015 & $\begin{array}{l}\text { Filip } \\
\text { Kořínek }\end{array}$ \\
\hline 3 & $\begin{array}{l}\text { radní od 2010; } \\
\text { místostarosta od } \\
2014\end{array}$ & Černošice & $\begin{array}{l}\text { nestraník } \\
\text { za TOP09 }\end{array}$ & $\begin{array}{l}1978 \\
V \check{S}\end{array}$ & $\begin{array}{l}\text { místostarosta, } \\
\text { projektový } \\
\text { manažer }\end{array}$ & 12. 8.2015 & Petr Wolf \\
\hline 4 & $\begin{array}{l}\text { zastupitel } \\
\text { od 2006; radní } \\
\text { 2010-2014 }\end{array}$ & Černošice & $\begin{array}{l}\text { Věci } \\
\text { černošické }\end{array}$ & $\begin{array}{l}1976 \\
V \check{S}\end{array}$ & $\begin{array}{l}\text { daňový } \\
\text { poradce }\end{array}$ & 1.7. 2015 & $\begin{array}{l}\text { Tomáš } \\
\text { Hlaváček }\end{array}$ \\
\hline 5 & radní od 2010 & Černošice & Nezávislí & $\begin{array}{l}1976 \\
V \check{S}\end{array}$ & advokát & $\begin{array}{l}26.11 . \\
2015\end{array}$ & $\begin{array}{l}\text { Šimon } \\
\text { Hradílek }\end{array}$ \\
\hline 6 & $\begin{array}{l}\text { zastupitelka od } \\
\text { 2006; } \\
\text { místostarostka } \\
2010-2014\end{array}$ & Černošice & $\begin{array}{l}\text { Věci } \\
\text { černošické }\end{array}$ & $\begin{array}{l}1965 \\
V \check{S}\end{array}$ & $\begin{array}{l}\text { lektorka } \\
\text { paměti } \\
\text { a kognitivních } \\
\text { poruch dětí }\end{array}$ & 30.5 .2016 & $\begin{array}{l}\text { Daniela } \\
\text { Göttelová }\end{array}$ \\
\hline 7 & $\begin{array}{l}\text { majitel usedlosti } \\
\text { Č. p. 440, před } \\
\text { kterou se nachází } \\
\text { vizuální fakt }\end{array}$ & $\begin{array}{l}\text { Dolní } \\
\text { Černošice }\end{array}$ & & & $\begin{array}{l}\text { důchodový } \\
\text { věk }\end{array}$ & $\begin{array}{l}20.5 . \\
2017\end{array}$ & \\
\hline
\end{tabular}


Posilování efektivity a otevřenosti institucí „shora“ musí být nezbytně doprovázeno kulturními tlaky a požadavky ,zdola“ a posilováním politické gramotnosti a občanských kompetencí mezi širokou veřejností. Ve svobodné společnosti je nutné, aby veřejnost respektovala (ba podporovala) zájmovou a názorovou pluralitu, která přirozeně vede ke konfliktům, a aby ctila formální pravidla (instituce), která jsou sice nutně ne-dokonalá, avšak která jediná mohou zajišt'ovat spravedlivý i efektivní výkon politické moci, včetně pokojného zvládání občanských a politických konfliktů. Liberální prostředí předpokládá, že občané přijmou demokratické instituce za své, a že se cítí za jejich stav odpovědní, a pokud nejsou s jejich stavem spokojeni, jsou ochotni i schopni podnikat kroky k jejich reformě.

\section{Primární zdroje}

Zpráva z výzkumu Černošic, Semil a Hrádku nad Nisou. 2014. Praha: IPSOS, nepublikováno.

Výzkumný terénní deník vedený autorem v rámci zúčastněného pozorování z pozice zastupitele obce Černošice z let 2010-2017. 2017. Nepublikováno.

\section{Sekundární zdroje}

Prameny

Pamětni kniha Dolni Černošice. 1919. Dobřichovice: Státní oblastní archiv Praha-západ.

\section{Literatura}

ALEXANDER, Jeffrey. 2006. The Civil Sphere. Oxford: Oxford University Press.

ANDERSON, Benedict. 2003. Pomyslná společenství. Pp. 239-269 in Miroslav HROCH (ed.). Pohledy na národ a nacionalismus. Praha: Sociologické nakladatelství.

ARON, Raymond. 1993. Demokracie a totalitarismus. Brno: Atlantis.

BECK, Ulrich. 2007. Vynalézáni politiky. K teorii reflexivni modernizace. Praha: Sociologické nakladatelství. BOUBÍN, Jiří. 2008. Desetiletí slučování, rozlučování a změn hranic obcí politického okresu smíchovského 1919-28. Diplomová práce. Ústav českých dějin, Filozofická fakulta, Univerzita Karlova.

BROKLOVÁ, Eva. 1992. Československá demokracie. Politický systém ČSR 1918-1938. Praha: Sociologické nakladatelství.

CALHOUN, Craig. 1999. Habermas and the Public Sphere. Cambridge (MA): MIT Press.

CEJNAR, Pavel. 2015. „O nálepkách.“ Černošice. Informační list. Listopad 2015.

DELANTY, Gerard. 2011. „Cultural diversity, democracy and the prospect of cosmopolitanism: a theory of cultural encounters." The British Journal of Sociology 62(4): 633-656.

ERIKSON, Erik. 1974. Dimensions of a New Identity. New York: Norton.

ESS 2008. Download ESS Round 4 [online]. Cit. 10. května 2010 (http://www.europeansocialsurvey.org).

FLEISSNER, Kamil a Karel B. MÜLLER. 2016. „Radniční listy jako hlásné trouby politiků? Místní periodika jako indikátory demokratizace na lokální úrovni.“ Mediální studia/Media Studies 10(1): $113-139$.

FRIČ, Pavol a kol. 2008. Vỉdcovství českých elit. Praha: Grada.

GIDDENS, Anthony. 1998. Di̊sledky modernity. Praha: Sociologické nakladatelství.

GOFFMAN, Erving. 1956. Presentation of Self in Everyday Life. New York: Random House.

HABERMAS, Jürgen. 2000. Strukturální preměna veřejnosti. Praha: Filosofia. 
HABERMAS, Jürgen. 2001. The Postnational Constellation. Political Essays. Cambridge: Polity Press. HEUMOS, Peter. 1996. „Zhroucení jednoho systému. Osm tezí k rozpadu ČSR v letech 1938-1939.“ Déjiny a současnost 18(2): 25-28.

HILF, Rudolf. 1996. Němci a Češi. Sousedstvi ve střední Evropě, jeho význam a proměny. Praha: Prago Media News.

HOLÝ, Ladislav. 2001. Malý český člověk a skvělý český národ. Praha: Sociologické nakladatelství.

HOOVER, Keith. 1997. The Power of Identity. Politics in a New Key. Chatham: Chatham House Publishers.

HROCH, Miroslav. 1999. V národním zájmu. Praha: Lidové noviny.

KELLY, Mills T. 2003. „Last Best Chance or Last Gasp? The Compromise of 1905 and Czech Politics in Moravia.“ Austrian History Yearbook 34: 279-301.

KLÍMA, Michal. 2015. Od totality $k$ defektni demokracii. Privatizace a kolonizace politických stran netransparentním byznysem. Praha: Sociologické nakladatelství

KOŘALKA, Jiří. 1996. Češi v habsburské řiši a v Evropě 1815-1914. Praha: Argo.

LINEK, Lukáš. 2010. Zrazeni snu? Struktura a dynamika postoju k politickému režimu a jeho institucím a jejich di̊sledky. Praha: Sociologické nakladatelství.

LUHMANN, Niklas. 2006. Sociálni systémy. Brno: Centrum pro studium demokracie a kultury.

LYONS, Pat. 2013. Adjectives of Democracy. Citizenships and Political Attitudes under Socialist and Liberal Democracy in the Czech Republic. Praha: Sociologické nakladatelství.

MALÍŘ, Jiří. 2014. Občanská společnost na Moravě. Brno: Matice moravská.

MARADA, Radim. 2003. Kultura protestu a politizace každodennosti. Brno: Centrum pro studium demokracie a kultury.

MLČOCH, Lubomír. 2006. Ekonomie di̊věry a společného dobra. Praha: Karolinum.

MORLEY, David. 2000. Home Territories. Media, Mobility and Identity. London: Routledge.

MOŽNÝ, Ivo. 1999. Proč tak snadno... Praha: Sociologické nakladatelství.

MÜLLER, Karel B. 2006. „The Civil Society-State Relationship in Contemporary Discourse: A Complementary Account from Giddens' Perspective.“ The British Journal of Politics \& International Relations 8(2): 311-330.

MÜLLER, Karel B. 2016a. Češi, občanská společnost a evropské výzvy. Mezi nacionalismem a liberalismem aneb od etnické exkluze k aktivni hranici. Praha: Triton.

MÜLLER, Karel B. 2016b. „K čemu instituce? Jsme přeci samí slušní lidé! Příčiny, důsledky a řešení nedůvěry v zastupitelské sbory v Česku. “Politologická revue/Czech Political Science Review 22(1) 5-39.

MÜLLER, Karel B. 2018. „Dobré vládnutí a jeho aktéři v postkomunistickém happyvillu aneb jak rozhodovat v zájmu těch, kteří nejsou slyšet." Acta Politologica 10(1): 57-85.

OECD. 2016. Society at a Glance: OECD Social Indicators [online]. Cit. 16. června 2017 (http://oe.cd/sag).

PITHART, Petr. 2014. „Úvaha o prezidentech na hradě českých králi̊.“Politologická revue/Czech Political Science Review 20(2): 5-18.

PEROUTKA, Ferdinand. 1991. Budováni státu I, II. Praha: Lidové noviny.

PETŘÍČEK, Miroslav. 1993. Znaky každodennosti čili krátké řeči téměr o ničem. Praha: Hermann \& synové.

POPPER, Karl. 1994. Otevřená společnost a její nepřátelé. Praha: OIKOYMENH.

PUTNAM, Robert. 1993. Making Democracy Work. New Jersey: Princeton University Press.

ROSE, Richard a William MISHLER. 2010. Political Trust and Distrust in Post-Authoritarian Context. Studies in Public Policy 474. University of Aberdeen: Centre for the Study of Public Policy.

ROTHSTEIN, Bo. 2004. „Social Trust and Honesty in Government: A Causal Mechanisms Approach.“ Pp. 13-30 in János KORNAI, Bo ROTHSTEIN a Susan ROSE-ACKERMAN (eds.). Creating Social Trust in Post-Socialist Transition, New York: Palgrave Macmillan. 
RUPNIK, Jacques. 2009. Př́liš brzy unavená demokracie. Rozhovor s Karlem Hvižd'alou. Praha: Portál. SARTORI, Giovanni. 1993. Teória demokracie. Bratislava: Archa.

SEIBT, Ferdinand. 1996. Německo a Češi. Praha: Academia.

SCHMITT, Carl. 2007. Pojem politična. Praha/Brno: OIKOYMENH/Centrum pro studium demokracie a kultury.

SEDLÁČKOVÁ, Markéta. 2012. Di̊věra a demokracie. Praha: Sociologické nakladatelství.

SHILS, Edward. 1975. Center and Periphery. Essays in Macro-Sociology. Chicago: Chicago University Press.

SZTOMPKA, Piotr. 1998. „Mistrusting Civility: Predicament of a Post-Communist Society.“ Pp. 191210 in Jeffrey ALEXANDER (ed.). Real Civil Societies. London: SAGE.

SZTOMPKA, Piotr. 2007. Vizuální sociologie. Fotografie jako výzkumná metoda. Praha: Sociologické nakladatelství.

TAYLOR, Charles. 1994. „Liberální politika a veřejnost.“ Pp. 17-53 in Milan ZNOJ (ed.). Liberální společnost. Praha: Filosofia.

URBAN, Otto. 1978. Kapitalismus a česká společnost. Praha: Svoboda.

URBAN, Otto. 1995. „Český liberalismus v 19. století.“ Pp. 15-27 in Petr BURIÁNEK, Milan ZNOJ, Jan HAVRÁNEK a Martin SEKERA (eds.). Český liberalismus. Texty a osobnosti. Praha: Torst.

USLANER, Eric. 2002. The Moral Foundation of Trust. Cambridge: Cambridge University Press.

VILÍMEK, Tomáš. 2010. Solidarita napřič hranicemi. Opozice v ČSSR a NDR po roce 1968. Praha: Vyšehrad.

\section{Autor}

Karel B. Müller je v současné době vedoucím Katedry politologie Fakulty mezinárodních vztahů Vysoké školy ekonomické v Praze. Profesně se věnuje otázkám občanské společnosti, demokratizace a politické kultury na evropské, národní i komunální úrovni. Je autorem řady monografií, vědeckých i popularizačních článků. V roce 2016 vyšla jeho poslední kniha Čěri, občanská společnost a evropské výzvy.

Kontakt: karel.muller@vse.cz 